\title{
PURIFICATION AND PROPERTIES OF HUMAN SEMINAL MALTASE
}

\author{
A. R. SHETH ANd SHANTA S. RAO \\ Reproductive Physiology Unit, Indian Cancer Research Centre, Bombay 12, India
}

(Received 7th September 1961, revised 8th May 1962)

\begin{abstract}
Summary. The maltase activity of human seminal plasma was studied by paper chromatographic and glucose oxidase methods and expressed in terms of the glucose liberated from the maltose substrate used. The specificity of maltase was established by selectively inhibiting the enzyme activity with tris buffer. Seminal maltase and amylase were separated and partially purified. Purified maltase preparation did not exhibit any amylase, maltose phosphorylase or transglucosidase activity. The maltase activity of semen is predominantly associated with seminal plasma and proceeds at maximal velocity at $\mathrm{pH} 6.0$. The prostate gland seems to contribute most of the enzyme activity to the seminal plasma. The significance of the presence of maltase in seminal plasma and also in cervical mucus is discussed.
\end{abstract}

\section{INTRODUCTION}

Although spermatozoa are capable of aerobic respiration, it has been shown that anaerobic glycolysis is of greater quantitative significance in the energy metabolism of mammalian spermatozoa. This has been clearly demonstrated in the case of the dog (Iwanow, 1931), the bull (Mann, 1946) and man (Davis \& Maccune, 1950; Birnberg, Sherber \& Kurzok, 1952; Vaishwanar, 1958). MacLeod (1941) demonstrated that human spermatozoa are capable of utilizing glucose, mannose and maltose in addition to fructose, which is the normal constituent of seminal plasma. The utilization of fructose by mammalian spermatozoa has been studied by Mann (1954). Although it is known that human spermatozoa can utilize various other sugars besides fructose, no detailed study has been made of the enzymes which bring about the utilization of these sugars. It is not known what role these enzymes play in the metabolism of spermatozoa. The presence of amylase (diastase) in human semen has been reported (Karassik, 1927).

The presence of a maltase in human seminal plasma has been demonstrated only recently (Sheth \& Rao, 1962a). The present investigation was carried out to discover the source of seminal maltase and to purify it and study its properties. An attempt has also been made to investigate the mechanism for the conversion of maltose into glucose. 


\section{MATERIALS AND METHODS}

Semen samples used for these studies were obtained from fertile donors and from men referred for infertility by the K.E.M. Hospital, Bombay. Seminal vesicular fluid was obtained by the split ejaculate method. MacLeod \& Hotchkiss (1942) demonstrated that during ejaculation of human semen the first portion of the ejaculate contains mainly the prostatic secretion and the second portion the secretion from the seminal vesicles.

The concentration of protein was determined by the method of Lowry, Rosebrough, Farr \& Randall (1951), citric acid by that of Saffran \& Desdstedt (1948), glycogen by that of Kemp, Adrienne \& Heigningen (1954), and phosphorus by the method of Weil-Malherbe \& Green (1951). Glucose was estimated by the paper chromatographic method of Sheth \& Rao (1959) and also by the glucose oxidase method of Dahlquist (1961).The latter method was slightly modified in order to increase its sensitivity. It was found necessary to add $7 \cdot 2 \mathrm{~N}$-sulphuric acid at the end of the reaction as suggested by Washko \& Rice (1961). The glucose oxidase used was obtained from Worthington Biochemicals. The procedure for the assay of glucose is briefly as follows: To $0.05 \mathrm{ml}$ of a solution containing glucose was added $1.0 \mathrm{ml}$ glucose oxidase reagent. A blank and standard, containing $0.05 \mathrm{ml}$ water and $0.05 \mathrm{ml}$ standard glucose solution $(0.1 \mathrm{mg} / \mathrm{ml})$ respectively, were included along with each set of the unknowns. Without delay, all tubes were incubated at $37^{\circ} \mathrm{C}$ for exactly $30 \mathrm{~min}$. At the end of the incubation period, $5.0 \mathrm{ml}$ sulphuric acid was added and mixed thoroughly. The resulting pink colour was measured in a Klett Summerson colorimeter with the green filter $(540 \mathrm{~m} \mu)$.

The maltase activity of seminal plasma was estimated as follows: to $0.5 \mathrm{ml}$ dialysed seminal plasma were added an equal volume of veronal buffer $\mathrm{pH} 5.5$ and $0.5 \mathrm{ml}$ of $0.14 \mathrm{M}$-maltose. Appropriate control mixtures were also prepared, one without the seminal plasma and the other without the substrate. The reaction and the control mixtures were incubated at $37^{\circ} \mathrm{C}$ for $24 \mathrm{hr}$. Two to three drops of toluene were added before the digestion mixtures were kept for incubation. The glucose liberated was measured as described above, either by the paper chromatographic method (Sheth \& Rao, 1959) or by the glucose oxidase method.

\section{RESULTS}

SPECIFICITY OF SEMINAL MALTASE

Since seminal plasma yields glucose with either of the two substrates glycogen or maltose, it was necessary to find out whether the hydrolysis of maltose was specifically due to maltase, or whether seminal amylase (Karassik, 1927) could also degrade maltose to glucose. This could be verified by inhibiting selectively either the amylase which is responsible for hydrolysing glycogen or the maltase responsible for hydrolysing maltose.

Dahlquist (1961) has reported that tris buffer inhibits activity of hog intestinal maltase. It was of interest to discover whether the tris buffer would inhibit maltase activity of seminal plasma also. To verify this, two reaction mixtures A and B were prepared. Mixture A contained $0.5 \mathrm{ml}$ seminal plasma, $0.5 \mathrm{ml}$ 
glycogen and $0.5 \mathrm{ml}$ tris buffer $\mathrm{pH} 6 \cdot 0$. Reaction Mixture B contained the same proportion of all the reactants, but instead of the veronal buffer it contained tris buffer. The reaction mixtures were incubated at $37^{\circ} \mathrm{G}$ for $2 \mathrm{hr}$. The glucose and maltose liberated in the mixtures were detected as already described (Sheth \& Rao, 1961). Pl. 1, Fig. 1 shows the chromatogram spotted with the

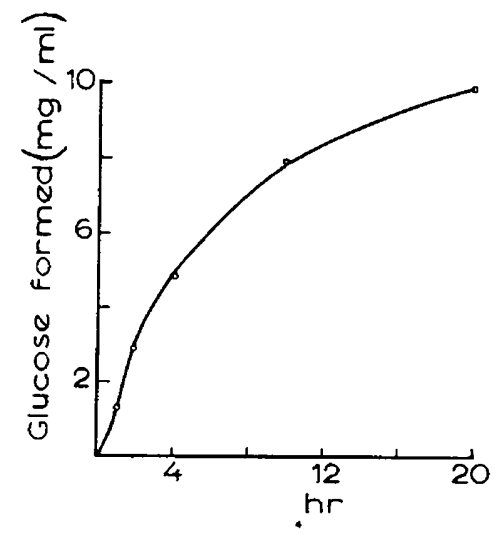

TEXT-FIG. 1. Effect of incubation time on the maltase activity. The digestion mixture contained $0.5 \mathrm{ml}$ each purified maltase, veronal buffer $\mathrm{pH} 6.0$ and $0.14 \mathrm{M}$-maltose.

two reaction mixtures. Only one band, with the same $\mathrm{Rf}$ value as that of the control maltose band, separated from the point which was spotted with the reaction mixture containing tris buffer whereas two bands, those of maltose and glucose, separated from the point spotted with the reaction Mixture B containing veronal buffer. This indicates that the tris buffer selectively inhibits the activity of the enzyme hydrolysing maltose to glucose, whereas amylase activity is not inhibited. The results show clearly that seminal plasma contains both amylase and maltase.

SEPARATION AND PURIFICATION OF SEMINAL MALTASE

Attempts were then made to purify seminal maltase. A $10 \mathrm{ml}$ sample of pooled seminal plasma was dialysed overnight against 1 litre of distilled water at $4^{\circ} \mathrm{C}$. At the end of $24 \mathrm{hr}$, the volume of dialysed seminal plasma was made up to $15 \mathrm{ml}$. One millilitre was kept aside as control, and to the remaining $14 \mathrm{ml}$ of seminal plasma was added an equal volume of cold acetone with constant stirring. The temperature was not allowed to rise above $4^{\circ} \mathrm{C}$. The solution was centrifuged for $15 \mathrm{~min}$ at $1000 \mathrm{rev} / \mathrm{min}$ (International Centrifuge, Model SBV) and the supernatant was discarded. The precipitate was dissolved in 10 $\mathrm{ml}$ phosphate buffer, $\mathrm{pH} 6.2$ and an ionic strength of $0.05 \mathrm{M}$. To this solution was added $5.5 \mathrm{~g}$ of solid ammonium sulphate so that the final salt concentration of the solution was $85 \%$ (calculated according to the method of Green \& Hughes, 1955). The solution was stirred vigorously and kept for $2 \mathrm{hr}$ at $30^{\circ} \mathrm{C}$. It was then centrifuged for $30 \mathrm{~min}$ at $1000 \mathrm{rev} / \mathrm{min}$ and the supernatant discarded. The precipitate was redissolved in $10 \mathrm{ml}$ phosphate buffer as indicated previously. The insoluble material was removed and discarded. The supernatant was dialysed in cold against distilled water. 
After dialysis, acetic acid was added dropwise to the dialysed supernatant until the $\mathrm{pH}$ of the solution was $5 \cdot 2$ and precipitate appeared. It is known that at this $\mathrm{pH}$ only maltase and not amylase gets precipitated (Monod \& Torriani, 1950). The solution containing the precipitated maltase was then centrifugated for $1 \mathrm{hr}$ at $1000 \mathrm{rev} / \mathrm{min}$ and the precipitate of purified maltase was dissolved in $10 \mathrm{ml}$ phosphate buffer $\mathrm{pH} 7.4$ and ionic strength $0.05 \mathrm{M}$, The Supernatant A was tested for amylase activity. It was able to liberate $7 \cdot 4 \mathrm{mg} / \mathrm{ml}$ of glucose from glycogen $(1 \%)$ in $24 \mathrm{hr}$ indicating that all the amylase activity was present. Activities of the dialysed seminal plasma and the purified enzyme towards maltose and glycogen were determined by the glucose oxidase method. It was observed that seminal plasma was capable of reacting equally well with glycogen and maltose, whereas the purified enzyme preparation did not liberate glucose from glycogen (Table 1). The results indicate that the purified

TABLE 1

COMPARISON OF MALTASE ACTIVITY OF DIALYSED SEMINAL PLASMA WITH PARTIALLY PURIFIED MALTASE

\begin{tabular}{l|c|c|c|c}
\hline & $\begin{array}{c}\text { Glucose liberated } \\
\text { when maltose was used as } \\
\text { substrate during 24 hr } \\
(\mathrm{mg} / \mathrm{ml})\end{array}$ & $\begin{array}{c}\text { Glucose liberated } \\
\text { when glycogen was used as } \\
\text { substrate during 24 hr } \\
(\mathrm{mg} / \mathrm{ml})\end{array}$ & $\begin{array}{c}\text { Protein } \\
(\mathrm{mg} / \mathrm{ml})\end{array}$ & $\begin{array}{c}\text { Specific } \\
\text { maltase } \\
\text { activity } \\
(\mathrm{mg} / \mathrm{ml})\end{array}$ \\
\hline Seminal plasma & $12 \cdot 0$ & $10 \cdot 0$ & $1 \cdot 2$ & $10 \cdot 0$ \\
Purified maltase & $7 \cdot 0$ & 0.0 & 0.013 & $533 \cdot 0$ \\
$\begin{array}{l}\text { Supernatant A } \\
\text { (containing amylase) }\end{array}$ & $2 \cdot 2$ & $7 \cdot 4$ & $0 \cdot 400$ & - \\
\hline
\end{tabular}

preparation was fifty-three times as active as the original seminal plasma in its activity towards maltose.

MECHANISM FOR CONVERSION OF MALTOSE TO GLUCOSE

It is known that maltose is converted to glucose by any of the following reactions: 1. By hydrolysis according to the equation:

$$
\mathrm{C}_{12} \mathrm{H}_{22} \mathrm{O}_{11}+\mathrm{H}_{2} \mathrm{O} \longrightarrow 2 \mathrm{C}_{6} \mathrm{H}_{12} \mathrm{O}_{6} \text {. }
$$

2. By transglucosidation according to the equation:

$$
\text { maltose }+ \text {-maltose } \longrightarrow \text { maltose triose + glucose. }
$$

3. By phosphorylation:

$$
\text { D-maltose }+P_{\mathbf{i}} \longrightarrow \text { B-D-Glucose-1-phosphate + glucose. }
$$

If transglucosidation was taking place, the maltose triose formed would have been detected by the paper chromatographic method. Pl. 1, Fig. 2 shows that maltose triose was not formed in the reaction mixture. Assay for maltose phosphorylase was carried out as suggested by Doudoroff (1955). Reaction mixture consisted of $0.5 \mathrm{ml}$ each of seminal plasma, phosphate buffer $(\mathrm{pH} 6.5$, $0.033 \mathrm{~m}$ ) and $0.14 \mathrm{M}$-maltose. Phosphate was measured initially and after $1 \mathrm{hr}$. No change in the phosphate level was detected; this indicates that maltose phosphorylase was absent. These experiments show that the conversion of maltose to glucose by seminal plasma is by hydrolysis only. 


\section{PLATE 1}
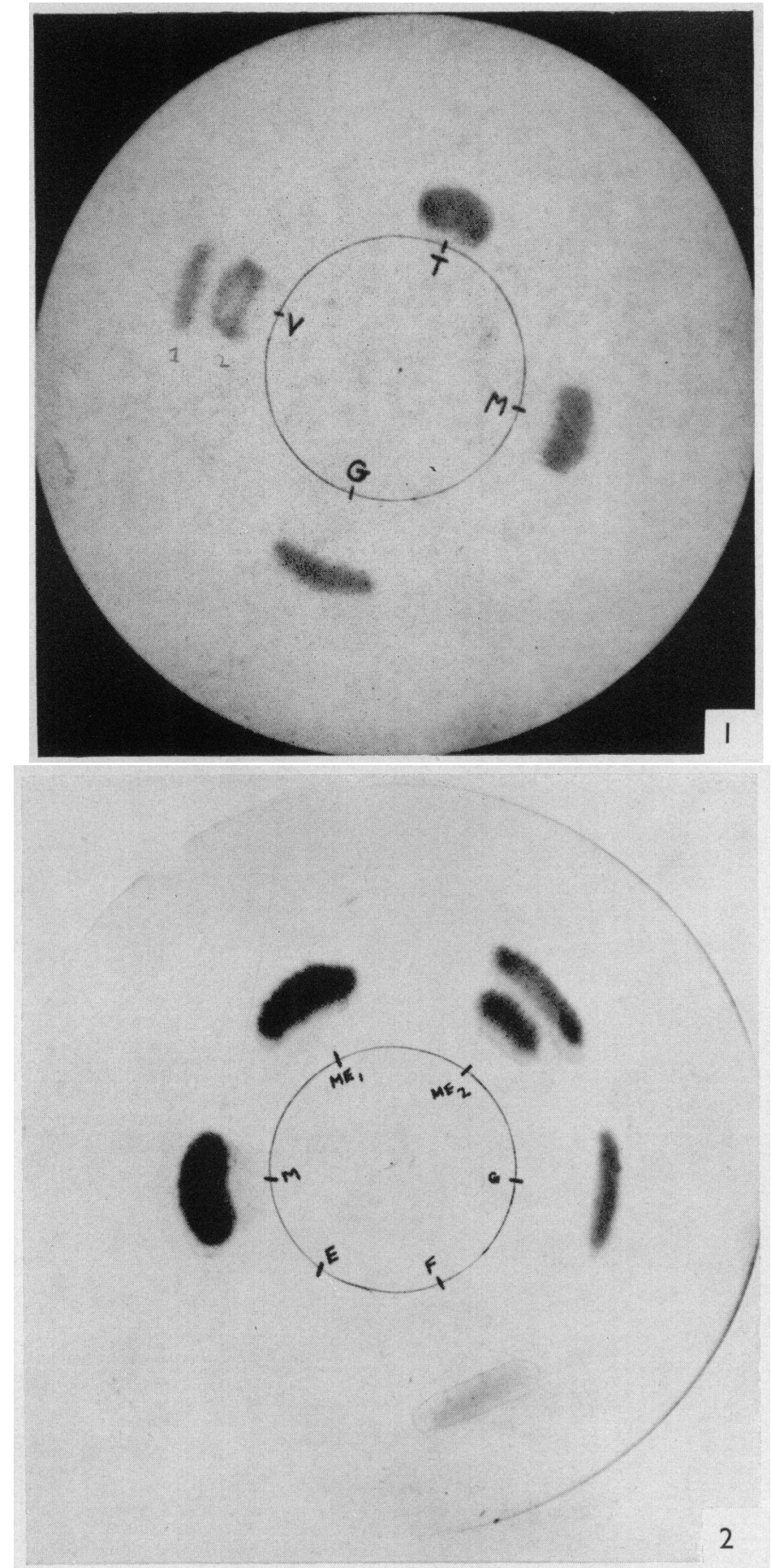

Frg. 1. A chromatogram showing the inhibition of seminal maltase by tris buffer. $\mathbf{G}=$ glucose standard; $\mathrm{V}=$ digestion mixture containing veronal buffer. Band 1 is of glucose and Band 2 is of maltose.

Frg. 2. A chromatogram showing the absence of maltose triose formation in the digestion mixture. $\mathbf{M}=$ maltose; $\mathbf{G}=$ glucose; $\mathbf{F}=$ fructose; $\mathbf{M E}_{\mathbf{1}}=$ digestion mixture at zero hours; $\mathrm{ME}_{2}=$ digestion mixture after $24 \mathrm{hr} ; \mathrm{E}=$ control digestion mixture without maltose. 
PROPERTIES OF PURIFIED MALTASE PREPARATION

The results depicted in Text-figs. 1, 2 and 3 indicate that reaction velocity is a function of time, $\mathrm{pH}$ and enzyme concentration. The reaction proceeds at maximal velocity at $\mathrm{pH} 6.0$. The amount of glucose formed is proportional to

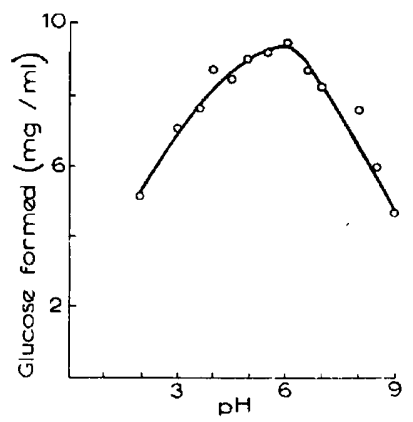

Text-Fig. 2. Effect of $p H$ on the purified maltase. The digestion mixtures contained $0.5 \mathrm{ml}$ purified maltase, $0.5 \mathrm{ml}$ of $0.14 \mathrm{M}$-maltose and $0.5 \mathrm{ml}$ veronal buffer of desired $\mathrm{pH}$.

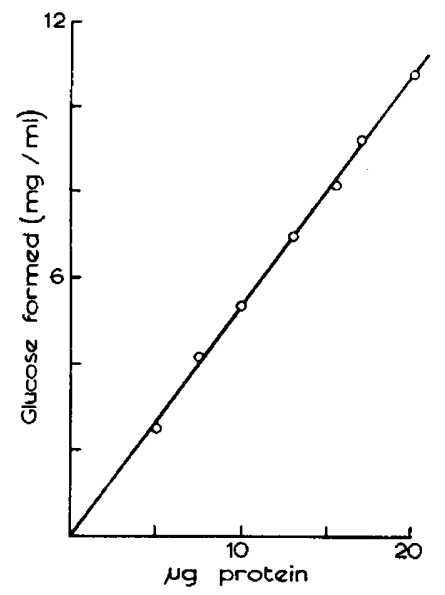

TEXT-FIG. 3. Effect of enzyme concentration on the reaction velocity. The digestion mixtures contained $0.5 \mathrm{ml}$ of $0.14 \mathrm{M}$-maltose, $0.5 \mathrm{ml}$ veronal buffer $\mathrm{pH} 6.0$ and $0.5 \mathrm{ml}$ enzyme in different concentrations in terms of protein.

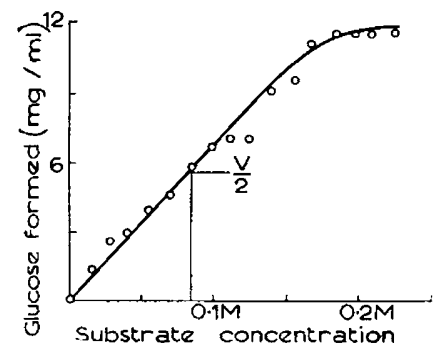

TEXT-FIG. 4. Effect of different concentrations of maltose on the enzyme activity. The digestion mixtures contained $0.5 \mathrm{ml}$ purified maltase, $0.5 \mathrm{ml}$ veronal buffer and $0.5 \mathrm{ml}$ maltose in different concentrations.

the enzyme concentration. The effect of increasing concentration of maltose on the rate of reaction is shown in Text-fig. 4. The Michaelis constant obtained was in range of 0.042 to $0 \cdot 121$. 
It was of interest to know the source of seminal maltase, whether it is secreted by the prostate, seminal vesicles or the testicular tissue. The secretion of the prostate was analysed for citric acid and fructose. It is known that most of the citric acid in seminal plasma is contributed by the prostate and the fructose by the seminal vesicles (Mann, 1954). Since no fructose could be detected in the prostatic secretion, it was considered that prostatic secretion was free from vesicular fluid. The maltase activity was determined in the prostatic fluid and split ejaculates. The results (Table 2) indicate that seminal maltase is derived mainly from the prostate.

TABLE 2

CITRIC ACID AND FRUCTOSE VALUES AND MALTASE AGTIVITY OF PROSTATIC AND SEMINAL VESICULAR SEGRETIONS

\begin{tabular}{|c|c|c|c|c|c|c|c|}
\hline Secretions & Samples & $\begin{array}{l}\text { Volume } \\
(\mathrm{ml})\end{array}$ & $\left|\begin{array}{c}\text { Sperm count } \\
\text { (million per } m l)\end{array}\right|$ & $\underset{(\%)}{\text { Motility }}$ & $\begin{array}{c}\text { Fructose } \\
(\mathrm{mg} / 100 \mathrm{ml})\end{array}$ & $\left|\begin{array}{c}\text { Citric acid } \\
(\mathrm{mg} / 100 \mathrm{ml})\end{array}\right|$ & $\begin{array}{c}\text { Maltase } \\
\text { activity } \\
\text { (mg/ml } \\
\text { glucose } \\
\text { liberated })\end{array}$ \\
\hline Prostatic fluid & Mean of 5 & - & - & - & - & 600 & $9 \cdot 1$ \\
\hline $\begin{array}{l}\text { First portion of } \\
\text { split ejaculate } \\
\text { (mostly prosta- } \\
\text { tic secretion) }\end{array}$ & $\begin{array}{l}\text { Sample A } \\
\text { Sample B } \\
\text { Sample C }\end{array}$ & $\begin{array}{l}2 \cdot 0 \\
1 \cdot 0 \\
3 \cdot 5\end{array}$ & $\begin{array}{r}115 \\
50 \\
80\end{array}$ & $\begin{array}{l}70 \\
30 \\
40\end{array}$ & $\begin{array}{l}179 \\
100 \\
250\end{array}$ & $\begin{array}{l}394 \\
174 \\
140\end{array}$ & $\begin{array}{l}9 \cdot 8 \\
9 \cdot 8 \\
7 \cdot 5\end{array}$ \\
\hline $\begin{array}{l}\text { Second portion of } \\
\text { split ejaculate } \\
\text { (mostlyseminal } \\
\text { vesicular secre- } \\
\text { tion) }\end{array}$ & $\begin{array}{l}\text { Sample A } \\
\text { Sample B } \\
\text { Sample C }\end{array}$ & $\begin{array}{l}5 \cdot 7 \\
1.5 \\
0.5\end{array}$ & $\begin{array}{l}38 \\
20 \\
30\end{array}$ & $\begin{array}{l}55 \\
60 \\
80\end{array}$ & $\begin{array}{l}363 \\
300 \\
443\end{array}$ & $\begin{array}{l}75 \\
94 \\
50\end{array}$ & $\begin{array}{l}3 \cdot 9 \\
2 \cdot 3 \\
4 \cdot 0\end{array}$ \\
\hline
\end{tabular}

It is unlikely that the testicular tissue contributes to the maltase activity of semen, since the semen samples obtained from vasectomized individuals were found to have about the same maltase activity as the semen of fertile donors. The mean maltase activity of the seminal plasma of five vasectomized individuals in terms of glucose liberated was $10.35 \mathrm{mg} / \mathrm{ml}$ (s.E. \pm 1.5$)$; and that of seminal plasma of five fertile individuals was $11 \cdot 1 \mathrm{mg} / \mathrm{ml}($ s.E. $\pm 1 \cdot 2)$.

\section{MALTASE ACTIVITY IN RELATION TO COUNT AND MOTILITY OF SPERMATOZOA}

Maltase activity of human semen was studied in relation to percentage motility, count per millilitre, volume and age. In the twenty-four samples studied, no correlation was observed between these and the maltase activity. The average value of glucose formed was found to be $9.46 \mathrm{mg} / \mathrm{ml}$ with a range of 4.4 to 18.3 $\mathrm{mg} / \mathrm{ml}$.

\section{MALTASE ACTIVITY OF GERVICAL MUCUS AND BLOOD SERUM}

The maltase activity of cervical mucus and blood serum was compared with that of the seminal plasma. Seminal plasma, cervical mucus and blood serum were dialysed for $24 \mathrm{hr}$. All the dialysed solutions were diluted to contain 200 
$\mu \mathrm{g} / \mathrm{ml}$ of protein, and maltase activity was determined as before. As seen in Table 3, it was observed that seminal plasma had the highest maltase activity.

TABLE 3

MALTASE ACTIVITY OF SEMINAL PLASMA, BLOOD SERUM AND CERVICAL MUCUS

\begin{tabular}{l|c|c}
\hline Secretion analysed & $\begin{array}{c}\text { Glucose liberated }(\mathrm{mg} / \mathrm{ml}) \\
\text { Mean of five samples }\end{array}$ & S.E. \\
\hline Seminal plasma & $10 \cdot 76$ & $\pm 1 \cdot 0$ \\
Cervical mucus & 3.70 & \pm 0.38 \\
Blood serum & 1.40 & \pm 0.27 \\
\hline
\end{tabular}

GLYCOGEN CONTENT OF HUMAN SEMEN

As already mentioned, it is likely that maltose in the semen is derived by the action of amylase on the glycogen present in semen. So it was of interest to find the glycogen levels in human semen. A total of thirty semen samples were analysed for their glycogen content. The mean glycogen level in these semen samples was $2.52 \mathrm{mg} / \mathrm{ml}$ with a range of 0.97 to $5.50 \mathrm{mg} / \mathrm{ml}$. The average reduction in glycogen level, when the semen samples were incubated at $37^{\circ} \mathrm{C}$ for $3 \mathrm{hr}$, was found to be $0.42 \mathrm{mg} / \mathrm{ml}$. Table 4 gives the results. To assess the

TABLE 4

GLYCOGEN LEVELS IN HUMAN SEMEN 30 MIN AFTER EJAGULATION AND AFTER 3 HR

\begin{tabular}{c|c|c|c}
\hline $\begin{array}{c}\text { Count } \\
\text { (million } \\
\text { per } \mathrm{ml})\end{array}$ & $\begin{array}{c}\text { Motility } \\
(\%)\end{array}$ & $\begin{array}{c}\text { Glycogen present } \\
\text { initially }(\mathrm{mg} / \mathrm{ml})\end{array}$ & $\begin{array}{c}\text { Reduction in glycogen } \\
\text { after } 3 \mathrm{hr}(\mathrm{mg} / \mathrm{ml})\end{array}$ \\
\hline 25 & 48 & 3.79 & 0.36 \\
15 & 36 & 2.89 & 0.53 \\
13 & 22 & 4.32 & 0.82 \\
nil & nil & 2.59 & 0.18 \\
30 & 40 & 1.82 & 0.34 \\
28 & 37 & 2.36 & 0.25 \\
23 & 41 & 2.64 & 0.50 \\
nil & nil & 0.97 & 0.10 \\
38 & 62 & 2.37 & 0.64 \\
25 & 38 & 1.33 & 0.60 \\
1 & nil & 1.87 & 0.30 \\
10 & 10 & $2 \cdot 45$ & 0.45 \\
\hline
\end{tabular}

glycolysable sugar available to spermatozoa from glycogen, an experiment was carried out in which $0.5 \mathrm{ml}$ dialysed seminal plasma was incubated with glycogen solution so that the reaction mixture contained $2.52 \mathrm{mg}$ glycogen per $\mathrm{ml}$ (the mean value of glycogen in semen as indicated above). During the $3 \mathrm{hr}$ of incubation, the seminal plasma liberated about $2 \mathrm{mg} / \mathrm{ml}$ of glucose.

\section{GLUCOSE GONCENTRATION IN SEMEN STORED AT ROOM TEMPERATURE FOR 3 HR}

Attempts were made to detect and measure glucose in the semen samples stored at room temperature for $3 \mathrm{hr}$. It was not possible to detect appreciable quantities of glucose by the chromatographic method, so the more sensitive glucose oxidase method was used. To $1 \mathrm{ml}$ of semen were added $4 \mathrm{ml}$ of absolute 
alcohol which was then centrifugated for $10 \mathrm{~min}$ at $1000 \mathrm{rev} / \mathrm{min}$. The supernatant was kept at $60^{\circ} \mathrm{C}$ overnight to remove alcohol. The residue was taken up in $0.5 \mathrm{ml}$ water and glucose was estimated. The results showed that the glucose formed in five semen samples was in the range of 100 to $250 \mathrm{\mu g} / \mathrm{ml}$ with a mean of $154 \mu \mathrm{g} / \mathrm{ml}$.

\section{DISCUSSION}

Studies on animal glycosidases have indicated that some enzymes belonging to this group occur in the reproductive organs and their secretions, sometimes in a high state of activity (Beyler \& Szego, 1954; Conchie, Findlay \& Levvy, 1956; Conchie \& Levvy, 1957; Levvy, McAllan \& Hay, 1961). Conchie \& Mann (1957) have shown that human semen and spermatozoa have about eight different glycosidases in various concentrations. The significance of these enzymes, in relation to sperm metabolism, has not been clearly shown.

The work reported here indicates that human seminal plasma has a high maltase activity. It is of interest to note that the presence of maltose in semen has not been reported by Kubicek \& Santavy (1958) who carried out detailed investigations on the sugars present in human semen. In the earlier work reported, Sheth \& Rao (1961) were also not able to detect maltose. This may be due to the fact that maltase activity of semen further hydrolysed the maltose to glucose, so that maltose as such could not be detected. In the present studies, it has been shown that the maltase activity of semen can be inhibited by tris buffer and thus it has been possible to demonstrate the formation of maltose in human semen.

Human semen is known to contain glycogen which, according to LaneRoberts, Sherman, Walker, Weisner \& Barton (1948), contributes about onesixth of the total glycolysable sugar. In the course of the present work, it was observed that glycogen concentration in human semen varies from 0.97 to $5.50 \mathrm{mg} / \mathrm{ml}$ of semen. Glucose that can be liberated from this glycogen is almost equal to the fructose available for sperm fructolysis on the basis of the results already reported (Sheth \& Rao, 1962b). In all probability, seminal amylase has the same specificity as salivary amylase. The maximum possible digestion by salivary amylase is to convert starch to maltose and other dextrines (Thorpe, 1960).

The experiment with the tris buffer, which selectively inhibits the maltase activity of semen, has also indicated that seminal amylase converts glycogen to maltose only. The present work strongly suggests that it is probably the amylase in semen that converts glycogen into maltose, which in its turn is converted into glucose by the action of maltase present in seminal plasma. In connexion with the presence of maltase in semen, the observations of Mann (1946) using bull and ram spermatozoa and those of Freund \& MacLeod (1958) using human spermatozoa are of great interest. Both these latter workers showed that spermatozoa utilize glucose in preference to fructose when both the sugars are present in the reaction mixture. Freund \& MacLeod (1958) have shown that added glucose inhibits fructose utilization by human spermatozoa. The earlier work of MacLeod (1941) has shown that human spermatozoa maintain maximum motility in the presence of glucose. 
During the course of the present work, it was also observed that when semen samples were kept at room temperature for over $3 \mathrm{hr}$ traces of glucose could be detected. Attempts were made to estimate glucose in semen samples kept at room temperature for a period of $3 \mathrm{hr}$. It could not be estimated by the chromatographic method, because the concentration was very low. It was possible, however, to estimate it by the more sensitive glucose oxidase method. The amounts detected were in the range of 106 to $250 \mathrm{\mu g} / \mathrm{ml}$. The experimental evidence indicates that glycogen in semen can supply to spermatozoa about the same amount of glycolysable sugar as seminal fructose. On basis of the amylase and maltase activity of semen, it should be possible to demonstrate the formation of glucose anywhere from 1.4 to $2.3 \mathrm{mg} / \mathrm{ml}$ of a semen sample kept at room temperature for $3 \mathrm{hr}$; but the actual values obtained for glucose were much lower $(100$ to $220 \mu \mathrm{g} / \mathrm{ml})$. These results suggest that it is likely that the glucose was utilized by the spermatozoa.

In the light of the work reported, it is worth while to consider whether the rate of fructolysis, as measured conventionally, can give a correct index of the glycolytic metabolism of human spermatozoa. It would be of interest to find out whether the maltase activity of semen affects the rate of fructolysis of human spermatozoa. If spermatozoa utilize glucose in preference to fructose, it would then mean that the rate of fructolysis of human semen would be affected by the maltase activity of seminal plasma.

It is of interest to note that cervical mucus also has maltase activity. Cervical mucus is also known to contain amylase (Breckenridge \& Pommerenke, 1951). The vaginal mucosa and also the endometrial epithelium (Reynolds, 1939) are known to contain a high content of glycogen. Hughes \& Syracuse (1945) and Novak (1945, cited by Hughes \& Syracuse, 1945) have also reported the widespread distribution of glycogen in the female reproductive tract. Like the cervical mucus, the uterine secretion may also have maltase activity. Thus the maltase activity of both seminal plasma and cervical mucus may play an important role in providing enough glucose to the metabolizing spermatozoa.

At present, it is not clear whether the presence of maltase in human semen has any other significance besides helping to provide spermatozoa with more glycolysable sugar. Conchie \& Findlay (1959) have discussed 'The possible function of the glycosidases in the penetration of mucoid barriers by spermatozoa'. In the light of these observations, the presence of maltase in human semen seems to be significant.

\section{ACKNOWLEDGMENTS}

It is a pleasure to acknowledge the encouragement and help given during the course of these studies by Dr V. R. Khanolkar, Director, Indian Cancer Research Centre. The authors are also grateful to Mr S. A. Bangalore for his technical assistance and to Drs R. W. P. Master and Govind Menon, Haffkine Institute, for suggestions and help during the course of these studies.

\section{REFERENCES}

BEYLER, A. L. \& Szego, C. M. (1954) Steroid hormone interactions as evidenced by modification of $\beta$-glucuronidase activity of the perputial glands of the rat. Endocrinology, 54, 334. 
Birnberg, G. R., Sherber, D. A. \& Kurzrok, R. L. (1952) Fructose and fructolysis in human semen. Amer. 7. Obstet. Gynec. 63, 877.

Breckenridge, M. A. B. \& Pommerenke, W. T. (1951) Analysis of carbohydrates in human cervical mucus. Fertil. Steril. 2, 29.

Conchie, J. \& Findlax, J. (1959) Influence of gonadoctomy, sex hormones and other factors on the activity of certain glycosidases in the rat and mouse. 7 . Endocrin. 18, 132.

Conchie, J., Findlay, J. \& Levvx, G. A. (1956) a-Mannosidase and other glycosidases in the tissue of the mouse and rat, with special reference to sex organs. Nature, Lond. 178, 1469.

Conchie, J. \& Levvy, G. A. (1957) Inhibition of glycosidases by aldonolactone of corresponding configuration. Biochem. 7. 65, 389.

Conchie, J. \& ManN, T. (1957) Glycosidases in mammalian sperm and seminal plasma. N Nature, Lond. 179, 1190.

Dahlquist, A. (1961) Determination of maltase and isomaltase activities with a glucose oxidase reagent. Biochem. 7. 80, 547.

Davis, M. E. \& Maccune, W. W. (1950) Fructolysis of human spermatozoa. Fertil. Steril. 1, 362.

Doudoroff, M. (1955) Disaccharide phosphorylases. Methods in Enzymology, Vol. 1, p. 225. Ed. S. P. Colowick and N. O. Kaplan. Academic Press, New York.

Freund, M. \& MacLeod, J. (1958) Effect of addition of fructose and of glucose on the fructolysis and motility of human semen. 7. appl. Physiol. 13, 506.

Green, A. A. \& Hughes, W. L. (1955) Protein fractionation on the basis of solubility in aqueous solutions of salts and organic solvents. Methods in Enzymology, Vol. 1. p. 67. Ed. S. P. Colowick and N. O. Kaplan. Academic Press, New York.

Hughes, E. C. \& Syracuse, N.Y. (1945) Relationship of glycogen to problems of sterility and ovular life. Amer. 7. Obstet. Gynec. 49, 10.

Iwanow, E. E. (1931) Zur Frage der Energetik der Spermatozoenbewegung. Z. Zucht. B, $20,404$.

Karassik, W. M. (1927) Uber die fermentativen Eigenschaften des Prostatasekrets im Zusammenhang mit der Bedentung der Prostata im der Spermatozoenbewegung. Z. ges. exp. Med. 53, 734.

Kemp, A., Adrienne, J. M. \& Heigningen, K. V. (1954) A colorimetric micro-method for the determination of glycogen in tissues. Biochem. $7.56,646$.

Kubicek, R. \& Santavy, F. (1958) Sugars and organic acids in seminal plasma of different mammals. Bull. Soc. Chim. biol., Paris, 40, 1603.

Lane-Roberts, C., Sherman, A., Walker, K., Weisner, B. \& Barton, M. (1948) Sterility and impaired fertility, p. 44. Hamish Hamilton, London.

Levvy, G. A., McAllan, A. \& Hay, A. J. (1961) Glycosidases in the corpus luteum. 7. Endocrin. 23, 19.

Lowry, O. H., Rosebrough, N. J., FArr, A. L. \& Randali, R. J. (1951) Protein measurement with the folin phenol reagent. 7. biol. Chem. 193, 265.

MAGLEOD, J. (1941) The effect of glycolysis inhibitors and of certain substrates on the metabolism and motility of human spermatozoa. Endocrinology, 29, 583.

MAcLeod, J. \& Hotchisiss, R. S. (1942) Spermatozoa and the distribution of certain chemical constituents in the human ejaculate. 7 . Urol. 48, 225.

ManN, T. (1946) Studies on the metabolism of semen. 3. Fructose as a normal constituent of seminal plasma. Site of formation and function of fructose in semen. Biochem. 7. 40, 481 .

ManN, T. (1954) Biochemistry of semen, p. 17 and p. 156. Methuen, London.

Monod, J. \& Torriani, A. M. (1950) De l'amylomaltase d'escherichia coli. Ann. Inst. Pasteur, 78, 65.

Reynolds, S. (1939) Physiology of uterus. Hoeber, New York.

Saffran, M. \& Denstedt, O. F. (1948) A rapid method for determination of citric acid. 7. biol. Chem. 175,849 .

Sheth, A. R. \& Rao, S. S. (1959) Fructose and fructolysis in human semen determined chromatographically. Experientia, 15, 314.

Sheth, A. R. \& Rao, S. S. (1961) Further studies on the identification and estimation of fructose in human semen by circular paper chromatographic method. Indian 7. med. Sci. 15, 24.

Sheth, A. R. \& Rao, S. S. (1962a) Maltase activity in human semen. Experientia, 18, 370.

Sheth, A. R. \& RAO, S. S. (1962b) Fructose levels in human semen determined chromatographically. Indian 7. med. Sci. 16, 709.

Thorpe, W. V. (1960) Biochemistry for medical students, 7th edn., p. 230, Churchill. London.

Vaishwanar, P. S. (1958) Fructolysis of human spermatozoa in semen. Amer. F. Obstet. Gynec. 75, 139.

Washro, M. R. \& Rice, E. W. (1961) Determination of glucose by an improved enzymatic procedure. Clin. Chem. 7, 542.

Weil-Malmerbe, H. \& Green, R. H. (1951) The catalytic effect of molybdate on the hydrolysis of organic phosphate bonds. Biochem. J. 48, 286. 